\title{
PERBEDAAN METODE PEMELIHARAAN IKAN HIAS PADA KELOMPOK PEMBUDIDAYA IKAN HIAS DI DESA KARANG SENTUL, KECAMATAN GONDANG WETAN, KABUPATEN PASURUAN, PROPINSI JAWA TIMUR
}

\author{
Akhmad Taufiq Mukti ${ }^{1 *}$, Muhammad Arief ${ }^{1}$, Luthfiana Aprilianita Sari ${ }^{1}$, Nina \\ Nurmalia Dewi ${ }^{1}$, Agung Pamuji Rahayu ${ }^{2}$ \\ ${ }^{1}$ Departemen Manajemen Kesehatan Ikan dan Budidaya Perairan, Fakultas Perikanan \\ dan Kelautan, Universitas Airlangga, \\ Kampus C Unair, jl. Mulyorejo, Surabaya 60115 \\ ${ }^{2}$ Fakultas Perikanan Universitas Islam Lamongan \\ Jl. Veteran no. 53A Lamongan Phone/Fax. 0322_324706 \\ * Corresponding Author: akhmad-t-m@fpk.unair.ac.id
}

\begin{abstract}
ABSTRAK
Tujuan kegiatan ini adalah mengaplikasikan metode mempercepat dan sinkronisasi kematangan dan pemijahan ikan hias air tawar melalui kombinasi pemberian pakan dan manipulasi lingkungan. Metode kegiatan adalah penyuluhan dan diskusi, pelatihan, praktek dan demoplot serta pendampingan berkelanjutan. Kelompok mitra PKM adalah Kelompok Pembudidaya Ikan (Pokdakan) Rasbora 15 dan Mina Jam 3 di Desa Karang Sentul, Kecamatan Gondang Wetan, Kabupaten Pasuruan, Propinsi Jawa Timur. Ilmu pengetahuan dan teknologi yang diberikan adalah metode peningkatan kualitas produksi budidaya ikan hias. Semangat dan motivasi kelompok mitra sangat tinggi dan antusias dalam menerima pengetahuan dan mengaplikasikan teknologi yang diberikan.
\end{abstract}

Kata Kunci: teknologi induce spawning, pemijahan, ikan lele, kelompok mitra

\section{PENDAHULUAN}

Budidaya ikan hias air tawar telah menjadi bagian hidup rakyat. Seiring dengan berkembangnya teknologi, maka sudah banyak jenis ikan hias yang dapat dikembangbiakkan dan dibudidayakan secara massal di Indonesia. Dunia perdagangan ikan hias mulai mendapat perhatian yang serius dari masyarakat. Bisnis ikan hias mampu memberikan jaminan keuntungan yang lebih bagi para pembudidaya ikan. Selain harga yang cukup tinggi, perkembangbiakan ikan hias relatif mudah, terlebih lagi dengan penerapan teknologi modern yang saat ini berkembang pesat. Siklus reproduksi atau pemijahan ikan hias relatif cepat (0,5-1,5 bulan), sehingga dalam jangka waktu satu tahun dapat dilakukan 8-24 kali pemijahan untuk sepasang induk ikan hias (pembenihan). Ikan hias mempunyai peran penting dalam menambah kesegaran, keindahan dan kesejukan lingkungan melalui jenis, warna, ukuran dan bentuk tubuhnya yang indah dan menarik.

Konsep pengembangan kewirausahaan dapat dilakukan melalui budidaya ikan hias yang merupakan industri utama yang penting bagi masyarakat (Lim dan Wong, 1997). Perdagangan ikan hias memainkan peran penting untuk peningkatan sosial ekonomi masyarakat kelas bawah di 
negara berkembang dengan investasi rendah (Bishnoi, 2013).

Penurunan kualitas produksi ikan hias air tawar yang dihasilkan oleh pembudidaya ikan, menyebabkan terjadinya penurunan drastis terhadap produksi dan harga ikan hias air tawar tersebut. Hal ini mengakibatkan kerugian sangat besar yang dialami oleh pembudidaya ikan hias, tidak terkecuali kelompok mitra PKM. Belum lagi melambungnya harga pakan ikan hias dari industri (pabrik pakan buatan).

Permasalahan sinkronisasi kematangan dan pemijahan induk ikan hias, rendahnya kualitas dan pertumbuhan serta tingkat kelangsungan hidup ikan hias yang rendah hingga saat ini menjadi perhatian serius bagi para pembudidaya ikan hias, termasuk kelompok mitra PKM. Hal ini diperoleh berdasarkan survei dan pemetaan lokasi serta diskusi yang dilakukan bersama dengan Ketua dan beberapa anggota kelompok mitra PKM sebelumnya. Karena itu, iptek tepat guna yang sederhana dan mudah untuk diterapkan secara langsung di lapangan oleh para pembenih dan pembudidaya ikan hias mitra kegiatan PKM ini sangat diperlukan untuk mengatasi permasalahan prioritas yang dihadapi oleh kelompok mitra PKM. Aplikasi iptek yang dapat dimanfaatkan sebagai alternatif adalah metode sinkronisasi kematangan dan pemijahan induk ikan hias yang didukung dengan pengaturan pola pakan induk ikan yang berkualitas dan manipulasi lingkungan untuk produksi ikan hias berkualitas dengan nilai jual tinggi.

Permasalahan lain yang menjadi prioritas kelompok mitra PKM adalah manajemen usaha, baik pembenihan maupun budidaya ikan hias. Kelompok mitra memiliki jumlah anggota 17 orang, tetapi segmentasi usaha belum tertata dengan baik antar anggota.
Pembenahan manajemen usaha dalam kelompok mitra penting dilakukan sebagai salah satu faktor penting dalam mendukung pengembangan usaha dan kelompok mitra di masa mendatang, Selama ini, arus keuangan (keluarmasuk atau pendapatan-pengeluaran) usaha budidaya ikan hias pada kelompok mitra PKM belum terdokumentasi dengan baik. Oleh karena itu, pengetahuan dan penataan manajemen usaha, terutama arus keuangan usaha juga menjadi sasaran target dalam kegiatan PKM ini pada kelompok mitra.

Manipulasi lingkungan, seperti suhu air media inkubasi telur (pembenihan) dan benih ikan hias (pembesaran/budidaya) efektif digunakan untuk menghasilkan ikan hias berkualitas dan bernilai jual tinggi. Saat ini juga menjadi tren di perdagangan ikan hias, yaitu ikan hias dengan kondisi morfologi tubuh yang terlihat abnormal atau berbeda dengan ikan normal memiliki harga jual lebih tinggi daripada ikan hias normal secara umum. Hal ini juga menjadi daya tarik kelompok mitra PKM untuk mendapatkan pengetahuan dan keterampilan dalam memproduksi ikan hias dengan penampilan berbeda (abnormal) menggunakan iptek yang sederhana dan mudah untuk diaplikasikan. Perlakuan manipulasi lingkungan budidaya (suhu air) juga dapat diaplikasikan secara cepat dan mudah untuk memproduksi ikan hias dengan morfologi tubuh yang diinginkan, sebagaimana penelitian Mukti et al. (2009, 2001) dan Mukti (2016). Perlakuan suhu juga dapat menghasilkan persentase ikan jantan lebih tinggi daripada betina, sebagaimana penelitian Strüssmann dan Nakamura (2002) dan Pradeep et al. (2012). Umumnya ikan hias jantan memiliki performa bentuk dan warna 
yang lebih indah daripada betina, sehingga ikan hias jantan lebih mahal harganya. Tapin (2010) juga menyatakan bahwa pada ikan pelangi ikan jantan tampak lebih menarik daripada betina. Pemanfaatan perlakuan manipulasi suhu air juga dapat meningkatkan kualitas ikan hias (Kumar dan Haniffa, 2012) atau ikan mas (Mukti, 2005).

\section{METODE PENELITIAN}

\section{Pelaksanaan Kegiatan PKM}

Kegiatan PKM dilaksanakan pada bulan Mei-Oktober 2018. Kegiatan ini dilaksanakan di kelompok mitra PKM Kelompok Pembudidaya Ikan (Pokdakan) Rasbora 15 dan Mina Jam 3 di Desa Karang Sentul, Kecamatan Gondang Wetan, Kabupaten Pasuruan, Propinsi Jawa Timur.

\section{Metode Pelaksanaan PKM}

Metode pendekatan dalam pelaksanaan PKM ini adalah melalui pemberian wawasan, ilmu pengetahuan dan teknologi (ipteks) yang sederhana dan mudah untuk diaplikasikan serta dikembangkan oleh masyarakat, khususnya kelompok mitra PKM. Nantinya diharapkan mitra (khalayak sasaran) kegiatan PKM ini dapat dijadikan percontohan (pilot project) lebih lanjut bagi masyarakat di sekitar lokasi mitra atau luar daerah. Sarana tempat penyuluhan dan pelatihan serta praktek secara langsung (demoplot) untuk kegiatan PKM ini telah tersedia di kelompok mitra, bahkan dapat juga nantinya bekerjasama dengan UPT Pengembangan Budidaya Air Tawar Umbulan, Pasuruan milik Dinas Perikanan dan Kelautan Propinsi Jawa Timur.

Pelaksanaan kegiatan yang dilakukan dalam kegiatan PKM ini, meliputi: Penyuluhan melalui tatap muka dan diskusi dua arah, Pelatihan dan peningkatan keterampilan aplikasi iptek pembenihan dan budidaya ikan hias, termasuk budidaya dan produksi pakan alami ikan hias, Praktek dan demoplot serta bimbingan teknis aplikasi iptek pembenihan dan budidaya ikan hias di lapang dan manajemen usaha.

Partisipasi kelompok mitra PKM ini adalah menyediakan sarana dan prasarana selama kegiatan dilaksanakan, seperti tempat pertemuan untuk penyuluhan dan pelatihan serta kolam atau wadah budidaya ikan hias untuk demoplot aplikasi ilmu pengetahuan dan teknologi yang diberikan.

\section{Uji Coba Manipulasi Lingkungan}

Uji coba manipulasi lingkungan dilakukan oleh kelompok mitra menggunakan metode sirkulasi air dan resirkulasi tertutup tanpa filter. Ikan yang dipelihara adalah ikan hias rainbow, guppy dan wader. Uji coba dilakukan pada bak beton dengan ukuran $1,5 \times 1,0 \times 0,6 \mathrm{~m}^{3}$. Substrat yang digunakan dalam pembenihan ikan hias terbuat dari serabut tali rafia plastik. Substrat ini berfungsi sebagai tempat melekatnya telur ikan hias saat memijah.

\section{Monitoring dan Evaluasi}

Monitoring dan evaluasi kegiatan pada kelompok mitra PKM secara berkala, sedangkan rencana tindak lanjut PKM dan pendampingan secara berkesinambungan di masa mendatang akan disusun dengan melibatkan beberapa pihak terkait. Pembinaan secara berkelanjutan kepada kelompok mitra PKM dan masyarakat sekitar akan diupayakan oleh Perguruan Tinggi pelaksana dan bekerjasama dengan Dinas terkait (Dinas Perikanan dan Kelautan) di tingkat Kabupaten Pasuruan maupun di tingkat Propinsi Jawa Timur. 

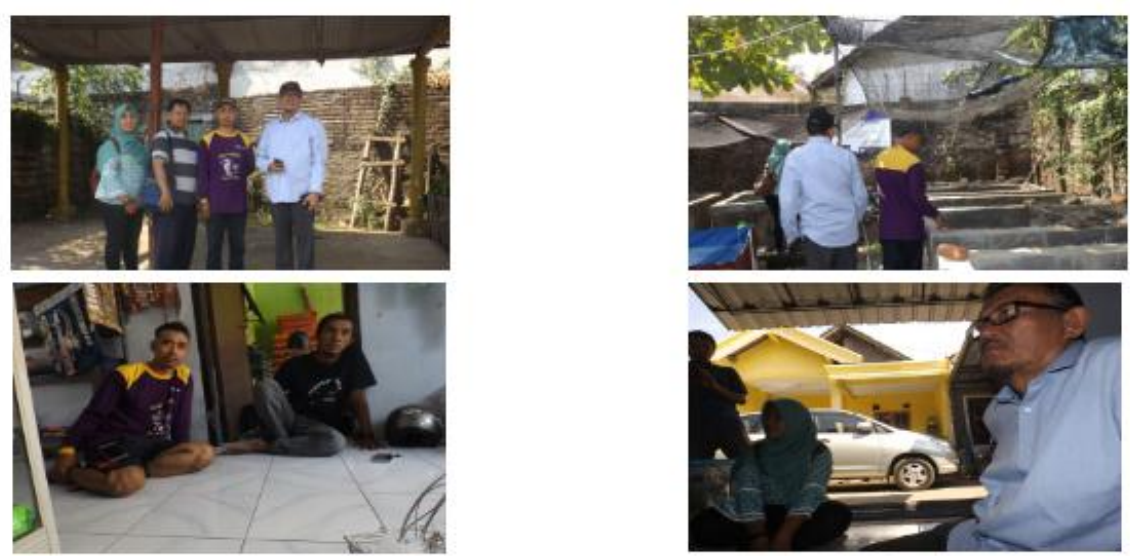

Gambar 1. Diskusi persiapan pelaksanaan pelatihan dan peninjauan lokasi budidaya ikan kelompok mitra PKM bersama Ketua Pokdakan Rasbora 15 dan pendamping dari UPT Pengembangan Budidaya Air Tawar Umbulan, Pasuruan
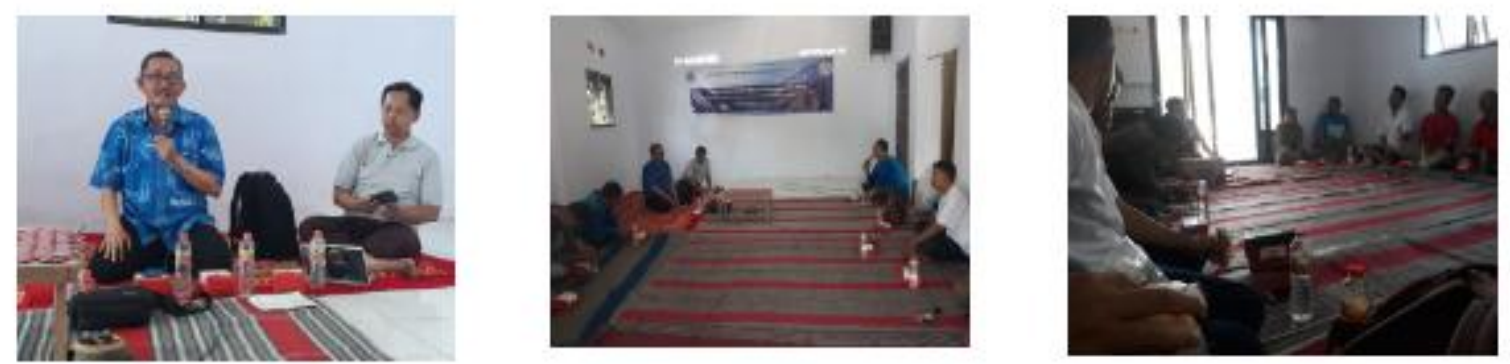

Gambar 2. Penyuluhan dan diskusi bersama Pokdakan Rasbora 15 dan Mina Jam 3 bertempat di Mushola tempat Pokdakan Rasbora 15
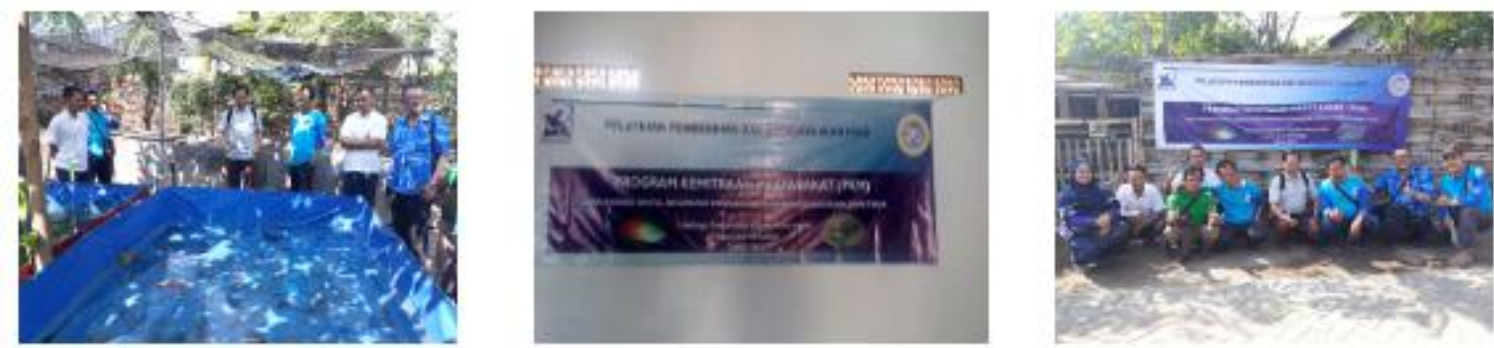

Gambar 3. Praktek lapang pada pelatihan pembenihan dan budidaya ikan hias
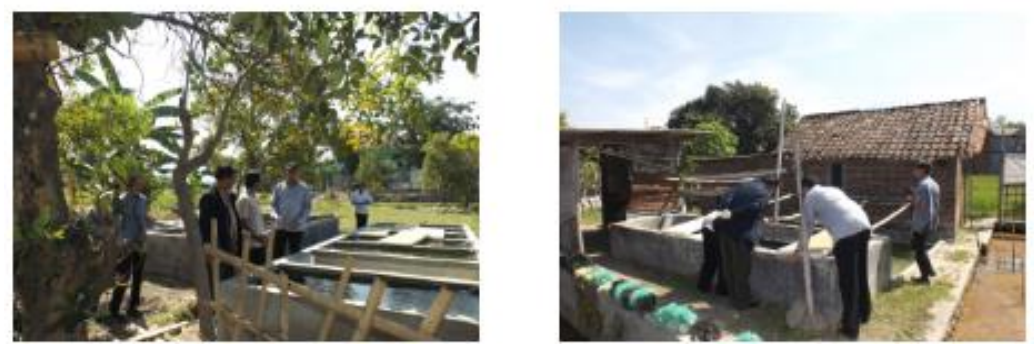

Gambar 4. Kegiatan monitoring dan evaluasi PKM pada kelompok mitra 


\section{HASIL DAN PEMBAHASAN}

Hasil kegiatan PKM ini adalah anggota kelompok mitra yaitu kelompok pembudidaya (Pokdakan) Rasbora 15 dan Mina Jam 3 sangat bersemangat dan antusias dalam kegiatan PKM ini (Gambar 1). Pada saat penyuluhan dan diskusi, anggota kelompok mitra berperan aktif dalam bertanya dan menyampaikan pengalaman mereka dan kendalakendala yang ditemui dalam budidaya ikan hias dan wader, terutama terkait pengelolaan kualitas air budidaya dan penanganan penyakit ikan (Gambar 2).

Materi pelatihan pembenihan dan budidaya ikan hias pada kelompok mitra PKM adalah Cara Budidaya Ikan yang Baik (CBIB) dan Cara Pembenihan Ikan yang Baik (CPIB). Saat diskusi juga dipaparkan dan dibahas cara produksi ikan hias berkualitas melalui metode yang sederhana dan relatif mudah dilakukan oleh pembudidaya ikan hias, khususnya kedua kelompok mitra PKM, seperti terlihat pada Gambar 2 dan 3.

Pada saat bersamaan juga diserahkan bantuan peralatan pembenihan dan budidaya ikan hias serta test kit pengukur kualitas air kepada kelompok mitra PKM. Hal ini disambut sangat baik dan antusias oleh kelompok mitra dikarenakan peralatan yang disumbangkan memang benar-benar diharapkan dan butuhkan serta sangat bermanfaat bagi kelompok mitra untuk mengembangkan pembenihan dan budidaya ikan hias dan wader.

Monitoring dan evaluasi kegiatan dilakukan sebagai upaya mengetahui hasil uji coba metode atau teknologi yang telah disampaikan dan diaplikasikan oleh kelompok mitra PKM. Monitoring dan evaluasi kegiatan juga dilaksanakan sebagai upaya kontrol terhadap keberlanjutan pelaksanaan kegiatan PKM, sebagaimana terlihat pada Gambar 4.

Berdasarkan hasil uji coba yang dilaksanakan oleh kelompok mitra PKM menunjukkan bahwa metode manipulasi lingkungan untuk pemeliharaan ikan hias, khususnya metode sirkulasi dan atau resirkulasi memberikan hasil yang positif dan lebih baik dalam meningkatkan kualitas ikan hias. Ikan hias air tawar yang dipelihara menggunakan sistem sirkulasi air secara terus menerus memperlihatkan pola kecerahan warna yang relatif sama dengan ikan hias yang dipelihara dengan sistem resirkulasi air meskipun tanpa filter. Hal yang berbeda adalah ikan hias yang dipelihara dengan sistem air stagnan (diam) memperlihatkan pola kecerahan warna tubuh yang agak pucat atau pudar, tidak secerah sistem sirkulasi maupun resirkulasi, meskipun kelangsungan hidupnya relatif sama, yaitu sekitar 95 persen, sebagaimana terlihat pada Tabel 1 . 
Tabel 1. Perbandingan kualitas ikan hias yang dipelihara menggunakan metode yang berbeda

\begin{tabular}{lcccl}
\hline \multirow{2}{*}{ Parameter } & \multicolumn{3}{c}{ Metode Pemeliharaan } & \multicolumn{1}{c}{ Keterangan } \\
\cline { 2 - 4 } $\begin{array}{l}\text { Kecerahan warna } \\
\text { tubuh }\end{array}$ & $\begin{array}{c}\text { Pucat dan } \\
\text { pudar }\end{array}$ & $\begin{array}{c}\text { Cerah dan } \\
\text { mengkilap }\end{array}$ & $\begin{array}{l}\text { Cerah dan } \\
\text { mengkilap }\end{array}$ & $\begin{array}{l}\text { Ikan yang dipelihara } \\
\text { adalah rainbow dan } \\
\text { wader }\end{array}$ \\
$\begin{array}{l}\text { Kelangsungan } \\
\text { hidup (\%) }\end{array}$ & 95 & 96 & & $\begin{array}{l}\text { Jumlah ikan 100 ekor } \\
\text { per bak }\end{array}$ \\
& & 95 & $\begin{array}{l}\text { Pakan yang diberikan } \\
\text { pakan buatan komersial } \\
\text { pabrik untuk ikan hias }\end{array}$ \\
\hline
\end{tabular}

\section{KESIMPULAN DAN SARAN Kesimpulan}

Kelompok mitra memiliki fasilitas memadai untuk pelaksanaan kegiatan PKM dan memiliki antusias tinggi untuk mengembangkan pembenihan dan budidaya ikan hias. Kelompok mitra memiliki semangat yang tinggi untuk mengembangkan diri menjadi pusat budidaya ikan hias dan wader di Jawa Timur.

\section{Saran}

Perlu pendampingan berkelanjutan untuk peningkatan budidaya ikan hias pada kelompok.

\section{UCAPAN TERIMA KASIH}

Ucapan terima kasih kami sampaikan kepada DRPM, Kemenristekdikti atas pendanaan kegiatan PKM tahun anggaran 2018 dan Rektor melalui Ketua Lembaga Pengabdian kepada Masyarakat Universitas Airlangga atas dukungan yang diberikan dalam pelaksanaan kegiatan PKM.

\section{DAFTAR PUSTAKA}

Bishnoi, R.K., 2013. Breeding and rearing of ornamental fishes: As an additional income generating source especially for women. Univ. $J$.
Environ. Res. Technol., 3(4), 447451.

Kumar, A. and Haniffa, M.A.K., 2012. Induction of tetraploidy in an ornamental fish koicarp, Cyprinus carpio L, using heat shock. J. Res. Animal Sci., 1, 013-019.

Lim, L.C. and Wong, C.C., 1997. Use of the rotifer, Branchionus calyciflorus Pallas in freshwater ornamental fish larviculture. Hydrobiologia, 358, 269-273.

Mukti, A.T., 2007. Perbandingan pertumbuhan dan perkembangan gonad ikan mas Cyprinus carpio Linn. diploid dan tetraploid. Berkala Penel. Hayati, 13(1), 27-32.

Mukti, A.T., Arsianingtyas, H. dan Subekti, S., 2009. Pengaruh kejutan suhu panas dan lama waktu setelah pembuahan terhadap daya tetas dan abnormalitas larva ikan nila (Oreochromis niloticus). J. Ilmiah Perik. Kel., 1(2), 163-167.

Mukti, A.T., Carman, O., Alimuddin dan Zairin Jr., M., 2015. Fekunditas, penetasan, kelangsungan hidup dan 
nisbah seks ikan threadfin rainbow Iriatherina werneri pada setiap kelompok tetas. Prosiding Simposium Nasional Ikan Hias. hal. 22-28.

Mukti, A.T., Rustidja, Sumitro, S.B. dan Djati, M.S., 2001. Poliploidisasi ikan mas (Cyprinus carpio L.). J. Ilmu-Ilmu Hayati BIOSAIN, 1(1), 111-123.

Mukti, A.T., 2016. Triploidi dan dimorfisme seks, performa reproduksi dan produksinya pada ikan nila Oreochromis niloticus. Disertasi. Sekolah Pascasarjana, Institut Pertanian Bogor. 100 hal.

Pradeep, P.J., Srijaya, T.C., Papini, A. dan Chatterji, A.K., 2012. Effects of triploidy induction on growth and masculinization of red tilapia [Oreochromis mossambicus (Peters, 1852) $\times$ Oreochromis niloticus (Linnaeus, 1758)]. Aquaculture, 344349, 181-187.

Strüssmann, C.A. dan Nakamura, M., 2002. Morphology, endocrinology and environmental modulation of gonadal sex differentiation in teleost fishes. Fish Physiol. Biochem., 26, 13-29.

Tappin, A.R., 2010. Rainbowfishes their care \& keeping in captivity. Art Publication. 484 p. 